\title{
THE USE OF ECONOMIC AND SOCIAL EXCHANGE PERSPECTIVES IN LINKING SALARY SATISFACTION, WORK RELATIONSHIP, AND EMPLOYEE PERFORMANCE
}

\author{
Nikodemus Hans Setiadi Wijaya*1 ${ }^{*}$ and Wa Ode Nur Hasana Rezeki*) \\ *) Department of Management, YKPN School of Business (STIE YKPN) Yogyakarta \\ Jl. Seturan Raya, Kabupaten Sleman, Daerah Istimewa Yogyakarta 55281, Indonesia
}

\begin{abstract}
The purpose of the current study is to propose the relationships among salary satisfaction, work relationship, and employee performance. A three-dimension of employee performance (i.e., task, adaptive, and contextual) is used in this study. The triachy measure of individual performance is suggested as a comprehensive measure to be employed in the business-oriented context. Economic- and social exchange theory were used to conceptualize the proposed hypotheses. A total of 118 responses from employees of an Indonesian company were analyzed in the hypotheses testing. The results suggested that both salary satisfaction and work relationship were positively related to employee performance. The independent variables were also positively related to all dimensions of employee performance. Furthermore, work relationship moderated the salary satisfaction-employee performance relationship. Theoretical and practical implications as well as the limitation of this study are discussed. Overall, this work advises that salary satisfaction and relationship at work are both necessary for employe performance improvement.
\end{abstract}

Keywords: salary satisfaction, work relationhsip, employee performance, economic exchange theory, social exchange theory

Abstrak:Tujuan penelitian ini adalah menguji hubungan antara kepuasan gaji, hubungan kerja, dan kinerja karyawan. Tiga dimensi kinerja karyawan yang mencakup kinerja tugas, adaptif, dan kontekstual, digunakan di dalam penelitian ini. Instrumen kinerja ini adalah ukuran yang komprehensif untuk mengukur kinerja karyawan. Teori Pertukaran Ekonomi dan Teori Pertukaran Sosial digunakan untuk membangun hipotesis dalam penelitian ini. Seratus delapan belas (118) sampel dari karyawan yang bekerja di sebuah perusahaan di Indonesia dianalisis untuk menguji hipotesis. Hasil analisis menunjukkan kepuasan gaji dan hubungan di tempat kerja berhubungan positif dengan kinerja karyawan. Kedua variabel independen tersebut juga berhubungan positif dengan setiap dimensi kinerja. Selanjutnya, implikasi teoritis dan praktis, serta keterbatasan penelitian dibahas. Secara keseluruhan, penelitian ini menyarankan bahwa kepuasan gaji dan hubungan di tempat kerja dibutuhkan untuk peningkatan kinerja karyawan.

Kata kunci: kepuasan gaji, hubungan kerja, kinerja karyawan, teori pertukaran ekonomi, teori pertukaran sosial

${ }^{1}$ Corresponding author:

Email: niko.wijaya@gmail.com 


\section{INTRODUCTION}

In the highly competitive business environment, every organization requires to improve its performance through boosting individual work performance. The work performance of organizational members in executing work tasks is also mandatory, because it will help the organization to improve team and overall organizational performance. Employee performance refers to a multi-facet concept measuring individual's work achievement after exerting required efforts on his/her job, engaged profile, and compassionate coworkers/other people around him/her (Pradhan and Jena, 2017). More specifically, extant literature has proposed the triachy model of employee performance that conceptualizes the three components of performance, i.e., task-, adaptive-, and contextual performance (Koopmans et al. 2014; Pradhan and Jena, 2017). Task performance is job explicit behaviors which are assigned to an employee or defined in the job description (Pradhan and Jena, 2017). Adaptive performance measures in the extent to which an employee can adjust him/her self to the changing working situation and requirements. Lastly, the authors define contextual performance as prosocial behaviors performed by an employee in workplace.

This study proposes that salary satisfaction and work relationship may be the significant factors for enhancing individual performance (Biggs et al. 2016; Gupta et al. 2012). However, it has been little attempts to investigate the influences of salary satisfaction and work relationship on the performance dimensions as mentioned. By drawing on economic- and social exchange theory (Blau, 1964; Cropanzano and Mitchell, 2005; Shore et al. 2006) and using a set of data taken from employees working in an Indonesian state-owned enterprise, the goal of the current study is to conceptualize and examine the different effects of salary satisfaction and work relationship on the performance construct and the dimensions (Pradhan and Jena, 2017). Since each performance dimension may produce deferring aspects of individual performance and all are important for organizational effectiveness, this study may contribute in giving deeper insights on how employees' satisfaction to their salary and their perception of work relationship can lead to their overall performance.
This study used a state-owned company as the study context. Nowadays, increasing organizational competitiveness through improving their performance of members is essential for all types of organizations. In the context of this work, therefore, examining the relationships among salary satisfaction, work relationship (which both can be conditioned by organizations) and employee performance is also necessary. For managers, the findings may thus contribute to provide understanding on the importance of improving salary satisfaction and work relationship.

\section{METHODS}

Respondents of this study were taken from an Indonesian state-owned enterprise named PT. Pelabuhan Indonesia II or PT. Pelindo II. This enterprise is a logistic company, more specifically, it manages and develops ports. This corporate employs more than 5,500 employees working in the head office and 13 branch offices located in 10 provinces. PT. Pelabuhan Indonesia II has a salary system that assures members are treated fairly in the payment procedure and outcome. The system thus eliminates the possibility of salary discrimination based personal attributes such as gender, race, religion, and others. Research survey was conducted in the head office located in Northern Jakarta. A total of 557 employees were working in the office when the survey distribution was conducted. An Indonesian paper-based survey was chosen. The Indonesian administrated survey was used, because the target respondents were presumed to be unfamiliar with English. A formal request was sent to get permission from the authorized person of the organization. A total of 150 employees were selected randomly, covering $27 \%$ of the total employees. Finally, 118 responses were collected, representing $79 \%$ of responses rate. All responses were usable. This study employed several statistical analyses, namely (1) validity and reliability analysis, (2) descriptive statistics, (3) correlation analysis, (3) and hierarchical regression analysis.

All items of the study variables were operationalized using a 5-point Likert scale which anchored from strongly disagree (1) to strongly agree (5). Validity and reliability assessment in the SPSS were performed to check all measurements. For construct validity evaluation, the cut-off value for loading was 0.50 . The value was a criterion for validity scores of the sample size in this study (Hair et al. 2010). In the first validity 
testing, items with loading values less than 0.50 were eliminated. The results of the second validity testing were shown in Table 1 . The reliability testings were performed by including valid items. The expected value for Cronbach's Alpha was 0.70 or higher. For employee performance, reliability assessment was applied to both their dimensions and the constructs. As reported later, the results of validity and reliability of the study variables were all achieved the expected values, thus valid and reliable.

Salary Satisfaction. A four-scale measurement was developed for this study. A sample item is "My Company has given alary according to the salary regulation"(see the Appendix A for more details). The alpha for this measurement was 0.89 .

Work Relationship. A nine-item developed by Biggs et al. (2016) was used to measure the perception of employees about the work relationship quality. This scale consist of 3 dimensions, i.e., individual-, supervisory, and organizational work relationship. Each dimension consists of 3 items. In the first testing, each of one items of individual and organizational work relationship has to be dropped due to low loadings. The alpha for individual-, supervisory-, and organizational work relationship were 0.77 (with 2 items), 0.80 , and 0.72 (with 2 items), respectively. The overall alpha for this measurement was 0.81 . However, only the overall mean score of work relationship was used in the correlation and regression analyses.

Employee Performance. A total of 33 items developed by Pradhan and Jena (2017). Six items were associated to task performance, 7 to adaptive performance, and 10 to contextual performance. In the first testing, one item of adaptive performance was dropped due to a low loading. Also, two items of contextual performance were dropped due to low loadings. The alpha for task-, adaptive-, and contextual performance were $0.80,0.70$ (with 6 items), and 0.82 (with 8 items), respectively. The overall alpha for this measurement was 0.90 . The mean scores of each dimension and overall performance were calculated and used to test the proposed hypotheses.
Table 1 . Validity assessment results

\begin{tabular}{|c|c|}
\hline Item Code & Loading of second Testing \\
\hline SS1 & 0.90 \\
\hline SS2 & 0.87 \\
\hline SS3 & 0.90 \\
\hline SS4 & 0.81 \\
\hline WI1 & 0.90 \\
\hline WI2 & 0.90 \\
\hline WI3 & Dropped \\
\hline WS1 & 0.84 \\
\hline WS2 & 0.86 \\
\hline WS3 & 0.85 \\
\hline WO1 & 0.89 \\
\hline WO2 & 0.89 \\
\hline WO3 & Dropped \\
\hline TP1 & 0.74 \\
\hline TP2 & 0.77 \\
\hline TP3 & 0.86 \\
\hline TP4 & 0.71 \\
\hline TP5 & 0.60 \\
\hline TP6 & 0.51 \\
\hline AP1 & 0.63 \\
\hline AP2 & 0.73 \\
\hline AP3 & 0.57 \\
\hline AP4 & 0.53 \\
\hline AP5 & Dropped \\
\hline AP6 & 0.67 \\
\hline AP7 & 0.66 \\
\hline CP1 & 0.59 \\
\hline $\mathrm{CP} 2$ & 0.64 \\
\hline CP3 & 0.75 \\
\hline $\mathrm{CP} 4$ & 0.77 \\
\hline CP5 & 0.71 \\
\hline CP6 & Dropped \\
\hline CP7 & 0.64 \\
\hline CP8 & 0.54 \\
\hline CP9 & Dropped \\
\hline CP10 & 0.71 \\
\hline
\end{tabular}

Note: $\mathrm{SS}=$ Salary Satisfaction, WI $=$ Individual Work Relationship, WS = Supervisory Work Relationship, $\mathrm{WO}=$ Organizational Work Relationship, TP = Task Performance, $\mathrm{AP}=$ Adaptive Performance, $\mathrm{CP}=$ Contextual Performance. 
Control Variables. Five control variables controlled for the effects of independent variables on the dependent variables. The control variables included gender (male $=1$, female $=1)$, age $(>20-25=1,>25-30=2,>30$ $35=3,>35-40=4$, and $>40-45=5$ ), the highest education attained (high school $=1$, associate degree $=2$, undergraduate $=3$, graduate (master's or doctoral) $=4$ ), organizational tenure (i.e., years working with the organization, $>1-5=1,>5-10=2,>10-15=3$, and $>15=4$ ), and management level (staff $=1$, first-line manager $=2$, middle manager $=3$, and top manager $=$ 4).

\section{Hypotheses Development}

\section{Economic- and Social Exchange Theory}

A business organization is one form of social contexts where people can interact, cooperate, and work together to achieve its common goals. Both economic- and social exchange relationships therefore exist in the organization (Wijaya, 2002). Based on economic exchange theory, economic exchange in an organization-employee relationship involves tangible, often short-term, contractual connections with a clear "this for that" resources (Cropanzano and Mitchell, 2005). In contrast, based on social exchange theory, social exchange relationships are based on trust between the parties and do not require an immediate reciprocity (Cropanzano and Mitchell, 2005; Deckop et al. 1999; Shih and Wijaya, 2014). In this study, the types of exchange relationship are used to explain the organization-employee relationship.

In all kinds of exchange relationships, parties involved are tied with the norm of reciprocity or exchange (Blau, 1964; Cropanzano and Mitchell, 2005). The norm of reciprocity describes that one party provides resources to another, vice versa. However, the forms of exchange may differ across the differing nature of relationship (economic or social) (Shore et al. 2006). An economic exchange relationship is based on impersonal binds, contractual agreements, and short-term orientation (Deckop et al. 1999). Economic exchange relationships commonly place emphasis on economic agreements and concrete resources in reciprocal mechanism such as payments without long-term implications (Wijaya, 2002). In contrast, a social exchange relationship is based on interpersonal binds, trust, and investment in the relationship are emphasized (Deckop et al. 1999). Cropanzano and Mitchell suggest that reciprocity this relationship involves open-ended manner, symbolic, and less concrete benefits given one to another party, vice versa.

\section{Salary Satisfaction and Employee Performance}

Salary is a periodic payment given by an employer to its employee (Sharma and Bajpai, 2011). By giving the payment, the employer may expect that the employee will return the salary payment with his/her actual efforts devoted to the organization. Obviously, the payment is a form of economic exchange. In most organizations, the salary payment policies, structure, and amount of salary may be based on an employment contract, stated in the company regulation, or clearly defined during their selection process (e.g., during employment interviews).

Since salary satisfaction (to note that other authors label the term as "pay satisfaction," e.g., Choudhury and Gupta, 2011) is the employee's attitude toward his/her salary, this study predicts that the more one satisfies with his/her salary, the better their performance. Based on economic exchange theory, when employees' satisfaction on their salary increases, they may reciprocate this by strengthening their efforts at workplace resulting the higher level of performance. More specifically, if the performance is related to the job description as required to perform by the employees, the well-performed task is the most concrete one that the employees can exchange. In addition, salary satisfaction will lead to the specific aspects of performance. That is, salary satisfaction will also promote employees' task-, adaptive-, and contextual performance. Thus, the following hypotheses are formed:

H1 : Salary satisfaction is positively related to overall employee performance.

H1a : Salary satisfaction is positively related to task performance.

H1b : Salary satisfaction is positively related to adaptive performance.

H1c : Salary satisfaction is positively related to contextual performance.

Work Relationship and Employee Performance

The relationship underlying social exchange theory is based on trust (Blau, 1964; Deckop et al. 1999), investment in the relationship, long-term orientation, and psychological (rather than contractual) attachment between the employees to the organization (Shaw, 
Dineen et al. 2009). Biggs et al. (2016) proposes that work relationship within an organization comprises the relationships between an employee and his/her coworkers, supervisor, and the organization. This study believes that a high work relationship quality manifests a high social exchange quality within an organization. Extant literature, for example, has proposed the relationship quality among team members (named as team-member exchange or TMX, e.g., Liao et al. 2013; Seer et al. 1995) and between an employee and his/ her supervisor (named as leader-member exchange or LMX, e.g., Graen and Uhl-Bien, 1995; Wijaya, 2019). All authors believe that the exchange relationships attributed in LMX and TMX are forms of social exchange relationships where trust, helping/supporting behavior, and psychological contract-based interrelation are emphasized. In addition, extant literature proposes a new facet of relationship in organizational context, namely "relations with the organization" that measures in the extent to which an employee feels comfortable working in the organization, cooperate and working with others, and fair employment treatments (Biggs et al. 2016).

Social exchange quality may lead to various individual performance (e.g., Atwater and Carmeli, 2009; Eisenberger et al. 2010; Farndale et al. 2011; Liao et al. 2013; Wijaya, 2019). One reason is because this exchange relationship improves employees' commitment (Biggs et al. 2016), which in turn, enhances performance (Dinc, 2017). It seems likely the better the work relationship quality, the higher the employee performance (Biggs et al. 2016). Also, the exchange quality is believed to promote the specific performance dimensions. Therefore, the following hypotheses are formed:

H2 : Work relationship is positively related to overall employee performance.

$\mathrm{H} 2 \mathrm{a}$ : Work relationship is positively related to task performance.

$\mathrm{H} 2 \mathrm{~b}$ : Work relationship is positively related to adaptive performance.

$\mathrm{H} 2 \mathrm{c}$ : Work relationship is positively related to contextual performance.

\section{Moderating Effect Work Relationship}

As hypothesized before, this study believes that both salary satisfaction is positively associated with individual performance. However, it is also suggested that the existence of social exchange relationship (low or high) attributed by the levels of work relationship may influence the strength of the relationship. Based on control theory, a payment given to employees can be a mean used by an organization to minimize undesirable behaviors, at the same time to maintain and enhance desirable ones (Wijaya, 2002). In the context of this study, employees (as the parties who are controlled) can be expected to contribute the organization in a form of performance to their organizations (as ones who control). In a lower level of work relationship where social exchange relationships are not improved, economic reciprocity thus seems likely to be more emphasized. The employees will see that role performance (as it may be required in the employment contract) is the most relevant resource return back to the organizations (Deckop et al. 1999). Contrarily, in a higher level of work relationship and when a salary is satisfied, the employees may reciprocate salary satisfaction with not only their efforts on work tasks, but also other benefits in many forms, such as their commitment (Biggs et al. 2016) and loyalty (Manurung, 2017). In the other words, the employees will perceive that their performance is only one mean among others to reciprocate the payment. Consistent with the above discussion, in a lower work relationship quality, salary satisfaction will particularly be the dominant determinant of employee performance. In such a situation, economic exchange relationships are more emphasized. In contrast, in a higher work relationship quality, salary satisfaction is not only determinant of employee performance, because they perceive that they can also reciprocate with other less concrete benefits. Thus, the following hypothesis is formed:

H3 : Work relationship moderates the relationship between salary satisfaction and overall employee performance. The strength of relationship is stronger in a lower level of work relationship level, rather than in a higher level of work relationship.

The research model is presented by Figure 1. As shown by the Figure, it is suggested that (1) salary satisfaction is linked to employee performance and its dimensions, (2) work relationship is linked to employee performance and its dimentions, and (3) work relationship would be a moderator on the relationship between salary satisfaction and employee performance. 


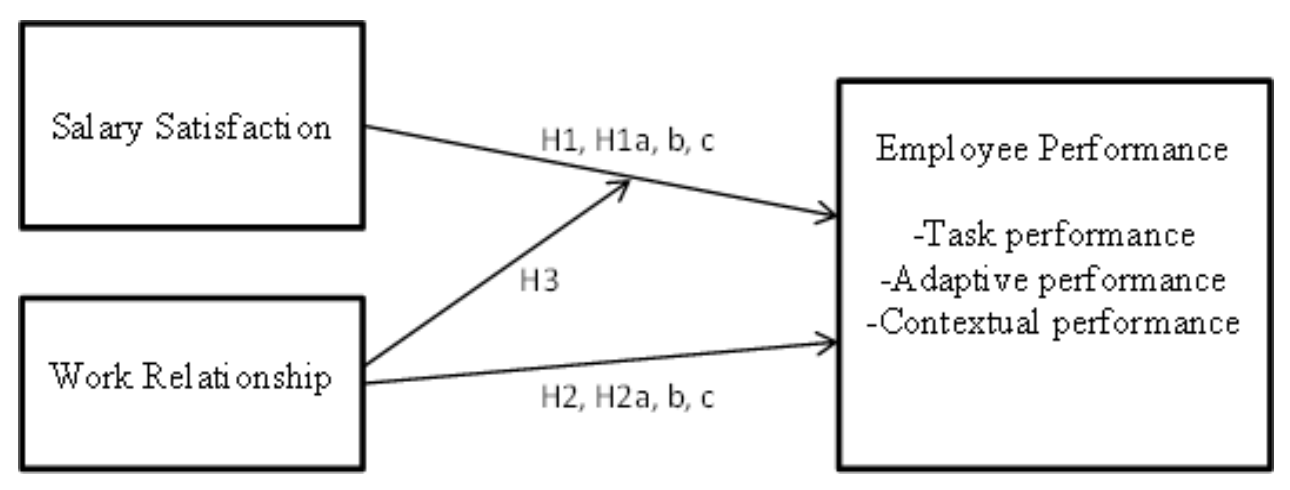

Figure 1. Research framework

\section{RESULTS}

Of the responding participants, $52 \%$ were male, $75 \%$ have finished their undergraduate degree, $53 \%$ in the age interval of $>25-30$ years, $61 \%$ in the organizational tenure interval of $1-5$ years, $88 \%$ were working as staffs. Table 2 shows the means, standard deviations, and correlation among the study variables. As shown, the study variables were positively correlated with each other in mediocre strength of magnitude, showing the expected directions as hypothesized.

\section{Hypotheses Testing Results}

A series of regression analysis were performed to evaluate the proposed hypotheses. Salary satisfaction and work relationship were regressed on overall performance and its dimensions. In addition, the datum was spit into two sets of data based on the levels of work relationship (the mean score of work relationship $=3.86$, the scores of work relationship below the score were coded as 0 or low work relationship, $\mathrm{N}=63$; the scores of work relationship higher the score were coded as coded as 1 or high work relationship, $\mathrm{N}=55$ ). Results of the regression analyses are shown in Table 3 and 4. The results demonstrate that among the five control variables, management level had the strongest effect on employee performance.

This study proposes salary satisfaction is also positively related to overall employee performance (H1), task performance (H1a), adaptive performance (H1b), and contextual performance (H1c). As shown in Table 3 and 4, salary satisfaction was positively related to overall performance $(\beta=0.57, p<0.001$, Model $1)$, task performance $(\beta=0.55, p<0.001$, Model 5), adaptive performance $(\beta=0.51, p<0.001$, Model $6)$, and contextual performance $(\beta=0.47, p<0.001$, Model 7). H1, H1a, H1b, and H1c were supported.
This study proposes work relationship is positively related to overall employee performance $(\mathrm{H} 2)$, task performance $(\mathrm{H} 2 \mathrm{a})$, adaptive performance $(\mathrm{H} 2 \mathrm{~b})$, and contextual performance (H2c). As shown, work relationship was positively related to overall performance $(\beta=0.58, \mathrm{p}<0.001$, Model 2$)$, task performance $(\beta=0.53, p<0.001$, Model 8$)$, adaptive performance $(\beta=0.52, p<0.001$, Model 9$)$, and contextual performance $(\beta=0.51, p<0.001$, Model 10). $\mathrm{H} 2, \mathrm{H} 2 \mathrm{a}, \mathrm{H} 2 \mathrm{~b}$, and $\mathrm{H} 2 \mathrm{c}$ were supported.

Finally, this study proposes that work relationship moderates the relationship between salary satisfaction and employee performance, in such ways that the effect of salary satisfaction on overall performance is stronger in the lower level of work relationship level, rather than in higher level of work relationship. As shown in Table 3, the effect of salary satisfaction on overall performance was 0.35 ( $\mathrm{p}<0.001$, Model 3 ) in the higher work relationship group and 0.38 ( $<<0.001$, Model 4$)$ in the lower work relationship group. Interestingly, the influence of work relationship was significant in the higher work relationship group ( $\beta=0.35, p<0.001$, Model 3$)$, but only marginally significant in the lower work relationship group $(\beta=$ $0.52, \mathrm{p}<0.1$, Model 4). To observe more deeply on these facts, further regression analyses were done by excluding all controls. It was found that the effect of salary satisfaction on overall performance was 0.31 (p $<0.05$ ) in the higher work relationship group and 0.48 $(\mathrm{p}<0.001)$ in the lower work relationship group. The effect of salary satisfaction was stronger in the lower work relationship group. H3 was thus supported.

This study aims at investigating the links among salary satisfaction, work relationship, and employee performance. The performance dimensions including task-, adaptive-, and contextual performance were used. The findings demonstrate that both salary satisfaction 
and work relationship are important for promoting employee relationship and all dimensions. Also, work relationship can moderate the relationship between salary satisfaction and employee persormance.

The current work is important for the literature related to the study variables. First, since extant literature has revealed the importance of salary satisfaction and work relationship on improving overall job satisfaction (Biggs et al. 2016; Chaudhry et al. 2011), this work discloses the importance of the factors in improving employee performance. In addition, this study also highlights the effects of both factors on the specific performances. Thus, the findings may offer empirical evidences on how salary satisfaction and work relationship are necessary to each of the performance dimension. Second, this study specifically offers an evidence on the meaning of work relationship on the effect of salary satisfaction on employee performance. It brings to a deeper understanding into the relationships. Third, this study explains both economic- and social exchange relationship on the effects of salary satisfaction and work relationship. Since salary satisfaction manifests an economic reciprocity from organizations to their employees, whereas, work relationship reflects a social exchange relationship quality within the organizations, this work may offer a different perspective about the nature of relationships.

Some limitations shall be noted. First, the data

Table 2. Means, standard deviations, and correlations

\begin{tabular}{llllllllllllll}
\hline Variable & Mean & SD & 1 & 2 & 3 & 4 & 5 & 6 & 7 & 8 & 9 & 10 & 11 \\
\hline Gender & .52 & .50 & & & & & & & & & & \\
Age & 1.92 & .85 & .12 & & & & & & & & & \\
Education & 3.06 & .60 & .10 & .06 & & & & & & & & \\
$\begin{array}{l}\text { Organizational } \\
\text { tenure }\end{array}$ & 1.42 & .56 & -.07 & $.33^{* *}$ & -.18 & & & & & & & \\
Management level & 1.16 & .49 & .01 & $.51^{* *}$ & $.23^{*}$ & .13 & & & & & & & \\
Salary satisfaction & 4.12 & .79 & -.11 & -.04 & .03 & .02 & .17 & $(.89)$ & & & & & \\
Work relationship & 3.86 & .63 & -.08 & $.19^{*}$ & -.01 & -.15 & -.02 & $.56^{* *}$ & $(.81)$ & & & \\
Task performance & 4.02 & .57 & -.03 & .02 & .07 & .05 & $.22^{*}$ & $.57^{* *}$ & $.52^{* *}$ & $(.80)$ & & & \\
Adaptive & 3.86 & .51 & .09 & .14 & .12 & .07 & $.26^{* *}$ & $.52^{* *}$ & $.48^{* *}$ & $.62^{* *}$ & $(.70)$ & & \\
performance & & & & & & & & & & & & & \\
$\begin{array}{l}\text { Contextual } \\
\text { performance }\end{array}$ & 3.86 & .55 & .05 & .11 & -.04 & .07 & $.30^{* *}$ & $.50^{* *}$ & $.48^{* *}$ & $.60^{* *}$ & $.74^{* *}$ & $(.82)$ & \\
$\begin{array}{l}\text { Employee } \\
\text { performance }\end{array}$ & 3.87 & .47 & .03 & .11 & .04 & .09 & $.31^{* *}$ & $.60^{* *}$ & $.55^{* *}$ & $.86^{* *}$ & $.86^{* *}$ & $.89^{* *}$ & $(.90)$ \\
\hline
\end{tabular}

Note. $\mathrm{N}=118 ; * \mathrm{p}<.05,{ }^{* *} \mathrm{p}<.01$ (two-tailed). Cronbach's alphas are shown in the parentheses.

Table 3. Regression analysis: overall performance as a dependent variable

\begin{tabular}{|c|c|c|c|c|}
\hline \multirow[t]{2}{*}{ Variable } & \multicolumn{4}{|c|}{ Overall performance } \\
\hline & Model $1(\mathrm{H} 1)$ & Model $2(\mathrm{H} 2)$ & Model 3 (H3, high WR) & Model 4 (H3, low WR) \\
\hline Gender & .10 & .08 & $.27 *$ & .06 \\
\hline Age & .01 & .03 & $.30 *$ & -.09 \\
\hline Education & -.02 & -.01 & .09 & -.05 \\
\hline Organizational tenure & .06 & $.14 \dagger$ & .05 & .14 \\
\hline Management level & $.20^{*}$ & $.29 * *$ & .08 & $.29 *$ \\
\hline Salary satisfaction & $.57 * * *$ & & $.35 * *$ & $.38 * *$ \\
\hline Work relationship & & $.58 * * *$ & $.35 * *$ & $.20 \dagger$ \\
\hline $\mathrm{F}$ & $12.91 * * *$ & $13.64 * * *$ & $6.12 * * *$ & $5.31 * * *$ \\
\hline $\mathrm{R} 2$ & .41 & .42 & .47 & .40 \\
\hline Adjusted R2 & .38 & .39 & .40 & .33 \\
\hline
\end{tabular}

Note. $\mathrm{N}=118, \mathrm{~N}$ high work relationship $=55, \mathrm{~N}$ low work relationship $=63 ; \dagger \mathrm{p}<.1, * \mathrm{p}<.05, * * \mathrm{p}<.01, * * * \mathrm{p}<.001$. 
Table 4. regression analysis: dimensions of performance as dependent variables

\begin{tabular}{|c|c|c|c|c|c|c|}
\hline \multirow{3}{*}{ Variable } & \multicolumn{6}{|c|}{ Dimensions of Employee performance } \\
\hline & Task & Adaptive & Contextual & Task & Adaptive & Contextual \\
\hline & $\begin{array}{c}\text { Model } 5 \\
\text { (H1a) }\end{array}$ & $\begin{array}{c}\text { Model } 6 \\
(\mathrm{H} 1 \mathrm{~b})\end{array}$ & $\begin{array}{c}\text { Model } 7 \\
(\mathrm{H} 1 \mathrm{c})\end{array}$ & $\begin{array}{c}\text { Model } 8 \\
(\mathrm{H} 2 \mathrm{a})\end{array}$ & $\begin{array}{c}\text { Model } 9 \\
(\mathrm{H} 2 \mathrm{~b})\end{array}$ & $\begin{array}{l}\text { Model } 10 \\
(\mathrm{H} 2 \mathrm{c})\end{array}$ \\
\hline Gender & .04 & $.14 \dagger$ & .11 & .02 & .12 & .10 \\
\hline Age & -.04 & .07 & .00 & -.02 & .08 & .02 \\
\hline Education & .03 & .07 & -.11 & .04 & .08 & -.01 \\
\hline Organizational tenure & .04 & .05 & .02 & .11 & .12 & .09 \\
\hline Management level & .13 & .12 & $.24^{*}$ & $.21 *$ & $.19^{*}$ & $.30 * *$ \\
\hline Salary satisfaction & $.55 * * *$ & $.51 * * *$ & $.47 * * *$ & & & \\
\hline Work relationship & & & & $.53 * * *$ & $.52 * * *$ & $.51 * * *$ \\
\hline $\mathrm{F}$ & $9.74 * * *$ & $9.09 * * *$ & $8.53 * * *$ & $9.00 * * *$ & $9.50 * * *$ & $9.92 * * *$ \\
\hline R2 & .35 & .33 & .32 & .33 & .34 & .35 \\
\hline Adjusted R2 & .31 & .29 & .28 & .29 & .30 & .31 \\
\hline
\end{tabular}

were taken from one company. Second, most of the respondents were staffs, thus the lowest level in managerial positions. They may cause a low generalizability. Future research may wish to target respondents from other types of companies and focus on higher levels on managerial positions. Third, since a cross-sectional design was used, future research may emphasize on the use of cross-lagged or multiple-rater data.

\section{CONCLUSIONS AND RECOMMENDATIONS}

\section{Conclusions}

The findings of this study demonstrates that salary satisfaction and work relationship are both important determinants for employee performance and the specific performances (task, adaptive, and contextual). The effect of salary satisfaction is stronger when work relationship is low than when it is high. Especially, this work contributes to explaining about how economicand social exchange theory can be used to describe the nature of the relationships of the study variables. For managerial practice, it is advised that managers can maintain the sense of distributive and procedural justice in the payment. Managers can improve work relationship as it is also important to leverage employee performance.

\section{Recommendations}

The findings suggest that in the high work relationship quality, the positive influences of salary satisfaction and work relationship are shown. Managers should be inspired that in high levels of salary satisfaction and work relationship are both important to improve employee satisfaction.

\section{RERERENCES}

Atwater L, Carmeli A. 2009. Leader-member exchange, feelings of energy, and involvement in creative work. The Leadership Quarterly 20(3): 264-275.

Biggs DM, Swailes S, Baker S. 2016. The measurement of worker relations: The development of a threecomponent scale. Leadership and Organization Development Journal 37(1): 2-12.

Blau PM. 1964 . Exchange and power in social life. New York: Wiley.

Chaudhry MS, Sabir HM, Rafi N, Kalyar MN. 2011. Exploring the relationship between salary satisfaction and job satisfaction: A comparison of public and private sector organizations. Journal of Commerce 3(4): 1-14.

Choudhury RR, Gupta V. 2011. Impact of age on pay satisfaction and job satisfaction leading to turnover intention: A study of young working professionals in India. Management and Labour Studies 36(4): 353-363.

Cropanzano R, Mitchell MS. 2005. Social exchange theory: An interdisciplinary review. Journal of Management 31(6): 874-900.

Deckop JR, Mangel R, Cirka CC. 1999. Getting more than you pay for: Organizational citizenship behavior and pay-for-performance plans. The Academy of Management Journal 42(4): 420428.

Dinc MS. 2017. Organizational commitment components and job performance: Mediating 
role of job satisfaction Pakistan Journal of Commerce and Social Sciences 11(3): 773-789.

Eisenberger R et al. 2010. Leader-member exchange and affective organizational commitment: The contribution of supervisor's organizational embodiment. Journal of Applied Psychology 95(6): 1085-1103.

Farndale E, Van Ruiten J, Kelliher C, Hope-Hailey V. 2011. The influence of perceived employee voice on organizational commitment: An exchange perspective. Human Resource Management 50(1): 113-129.

Graen GB, Uhl-Bien M. 1995. Relationship-based approach to leadership: Development of leadermember exchange (LMX) theory of leadership over 25 years: Applying a multi-level multidomain perspective. The leadership quarterly, 6(2): 219-247.

Gupta R, Hershey D, Gaur J. 2012. Time perspective and procrastination in the workplace: An empirical investigation. Current Psychology 31. doi:10.1007/s12144-012-9136-3

Hair JF, Jr, Black WC, Babin BJ, Anderson RE. 2010. Multivariate Data Analysis: A Global Perspective (Seventh Edition ed.). New Jersey: Prentice Hall.

Koopmans L et al. 2014. Measuring individual work performance: Identifying and selecting indicators. Work 48(2): 229-238.

Liao FY, Yang LQ, Wang M, Drown D, Shi J. 2013. Team-member exchange and work engagement: Does personality make a difference? Journal of Business and Psychology 28(1): 63-77.

Manurung SP. 2017. The effect of direct and indirect compensation to employee's loyalty: Case study at directorate of human resources in PT Pos Indonesia. Journal of Indonesian Applied Economics 6(1): 84-102.
Pradhan RK, Jena LK. 2017. Employee performance at workplace: Conceptual model and empirical validation. Business Perspective and Research, 5(1), 1-17.

Seers A, Petty MM, Cashman JF. 1995. Team-member exchangeunderteamand traditionalmanagement: A naturally occuring quasi-experiment. Group and Organization Management 20(1): 18-38.

Sharma JP, Bajpai N. 2011. Salary satisfaction as an entecedent of job satisfaction: Development of a regression model to determine the linearity between salary satisfaction and job satisfaction in a public and a private organization. Eropean Journal of Social Science 18(3): 450-461.

Shaw JD, Dineen BR, Fang R, Vellella RF. 2009. Employee-organization exchange relationships, HRM practices, and quit rates of good and poor performers. Academy of Management Journal, 52(5): 1016-1033.

Shih HA, Wijaya NHS. 2014. Career success and organizational commitment: The effects of match of career plans and self-construals. Paper presented at the Academy of Human Resource Development: Leading Human Resource Development through Research Houston, USA.

Shore LM, Tetrick LE, Lynch P, Barksdale K. 2006. Social and economic exchange: Construct development and validation. Journal of Applied Social Psychology 36(4): 837-867.

Wijaya NHS. 2002. Pengaruh Komponen Komitmen Organisasional pada Hubungan Persepsi Kaitan Kinerja-Gaji dan Organizational Citizenship Behavior. (Master), Universitas Gadjah Mada Yogyakarta.

Wijaya NH. S. 2019. Proactive personality, LMX, and voice behavior: Employee-supervisor sex (dis)similarity as a moderator. Management Communication Quarterly 33(1): 86-100. 